Cossa, N. A., L. Fasola, I. Roesler, and J. C. Reboreda. 2020. Impacts of traditional livestock farming on threatened sheldgeese (Chloephaga spp.) in Patagonia. Avian Conservation and Ecology 15(2):1. https://doi.org/10.5751/ACE-01630-150201

Copyright (C) 2020 by the author(s). Published here under license by the Resilience Alliance.

Research Paper

\title{
Impacts of traditional livestock farming on threatened sheldgeese (Chloephaga spp.) in Patagonia
}

\author{
Natalia A. Cossa ${ }^{1,2}$, Laura Fasola ${ }^{2,3}$, Ignacio Roesler ${ }^{1,2,4}$ and Juan C. Reboreda ${ }^{1}$ \\ ${ }^{1}$ Departamento de Ecología, Genética y Evolución \& Instituto de Ecología, Genética y Evolución de Buenos Aires (IEGEBA- \\ CONICET), Facultad de Ciencias Exactas y Naturales, Universidad de Buenos Aires, Pabellón II Ciudad Universitaria, Ciudad \\ Autónoma de Buenos Aires, Argentina, ${ }^{2}$ Programa Patagonia, Aves Argentinas, Ciudad Autónoma de Buenos Aires, Argentina, \\ ${ }^{3}$ Consejo Nacional de Investigaciones Científicas y Técnicas (CONICET)-Delegación Técnica Patagonia, Administración de \\ Parques Nacionales, Río Negro, Argentina, ${ }^{4}$ EDGE-ZSL affiliate
}

\begin{abstract}
Migratory sheldgeese (continental Upland Goose Chloephaga picta, Ashy-headed Goose C. poliocephala, and continental Ruddy-headed Goose C. rubidiceps) are endemic birds of southern South America. They are currently threatened by illegal hunting, overgrazing, and invasive predators. Because their breeding area is intensely grazed by sheep and cows, we studied the interaction of sheldgeese flocks and breeding pairs with livestock in the Tierra del Fuego and Santa Cruz provinces in Patagonia, Argentina. We conducted road-based surveys of sheldgeese flocks and breeding pairs from spring 2013 to summer 2016 to explore sheldgeese behavior. In addition, we monitored Upland Goose nests using camera traps and estimated nest daily survival rates in nests unprotected and protected from livestock with an electric fence. Sheldgeese flocks and breeding pairs were more frequently sighted alone than associated with livestock. Also, when sheldgeese foraged alongside livestock, there were fewer individuals resting and these allocated more time to forage than in the absence of livestock. We did not observe lower individual vigilance in sheldgeese flocks sharing foraging patches with livestock. Nests protected by electric fences had higher daily survival rates than unprotected ones. Our results indicate that one important conservation action should be to identify areas that concentrate a great number of breeding pairs of sheldgeese, and protect them from livestock, mainly during the peak of the reproductive season.
\end{abstract}

\section{Impacts de l'élevage de bétail traditionnel sur les ouettes menacées (esp. Chloephaga) en Patagonie}

RÉSUMÉ. Les ouettes migratrices (l'ouette de Magellan Chloephaga picta, l'ouette à tête grise C. poliocephala, et l'ouette à tête rousse C. rubidiceps) sont des oiseaux endémiques du sud de l'Amérique du Sud. Elles sont actuellement menacées par le braconnage, l'élevage extensif et les prédateurs invasifs. Dans la mesure où leur zone de reproduction est en grande partie occupée par des élevages d'ovins et de bovins, nous avons étudié l'interaction entre les volées et les couples reproducteurs d'ouettes avec le bétail dans les provinces de Tierra del Fuego et de Santa Cruz de la région argentine de Patagonie. Nous avons mené des enquêtes sur les volées d'ouettes et les couples reproducteurs du printemps 2013 à l'été 2016 pour explorer le comportement des ouettes. En outre, nous avons observé les nids d'ouettes de Magellan à l'aide de pièges photographiques et estimé les taux de survie quotidiens des nids non protégés et protégés du bétail par une clôture électrifiée. Les volées et les couples reproducteurs d'ouettes étaient plus fréquemment observés seuls qu'à proximité du bétail. En outre, lorsque les ouettes s'aventuraient à proximité du bétail, les individus au repos étaient moins nombreux, ce qui leur laissait plus de temps pour explorer la région qu'en l'absence de bétail. Nous n'avons pas observé de baisse de la vigilance individuelle dans les volées d'ouettes partageant des territoires de fourrage avec le bétail. Les nids protégés par des clôtures électrifiées présentaient des taux de survie quotidien supérieurs à ceux des nids non protégés. Nos résultats indiquent qu'une action importante pour la conservation consisterait à identifier les zones qui concentrent un grand nombre de couples d'ouettes reproductrices et à les protéger du bétail, principalement pendant le pic de la saison de reproduction.

Key Words: behavior; Chloephaga; conservation; endangered species; livestock; nest success; sheldgeese

\section{INTRODUCTION}

Livestock farming is the most widespread human activity and one of the greatest threats to biodiversity worldwide (Aagesen 2000, Rindfuss et al. 2008). Livestock can produce indirect impacts on biodiversity through habitat loss and degradation, global climate change, pollution, spread of invasive species, and disease transmission (Fleischner 1994, Hull et al. 2014). Moreover, livestock can also have a direct impact on wildlife through competition for resources (Edwards et al. 1996, Prins 2000,
Mishra et al. 2004), affecting wildlife behavior (Poudel et al. 2016) or causing damage to nests or young (Cossa et al. 2018).

Migratory sheldgeese (continental Upland Goose Chloephaga picta, Ashy-headed Goose C. poliocephala, and continental Ruddy-headed Goose C. rubidiceps; hereafter sheldgeese) are endemic threatened goose-like species from the southernmost part of South America (Argentina and Chile; MAyDS and AA 2017). All three species are declining because of the combined effect of threats at their wintering and breeding areas (BirdLife 
International 2020). They are illegally hunted in central Argentina during winter (Petracci et al. 2015a) and the population recovery is prevented by low reproductive success in breeding areas of Patagonia, where various negative factors operate (Canevari 1996, Madsen et al. 2003, Ibarra et al. 2009, Petracci et al. 2014).

Livestock farming is a traditional activity in Patagonia (INTA 2015) and intense grazing by sheep and cows causes the disappearance of tall grasses suitable for nesting (Kirsch 1969), a situation that could favor detection of nests by predators (Willson et al. 2001, Whittingham and Evans 2004). Additionally, on northern Tierra del Fuego island, where Ruddy-headed Geese were historically concentrated by the thousands (Cossa et al. 2017), predation of eggs, chicks, and adults of several species of ground-nesting birds has increased after the emergence of invasive populations of the gray fox (Lycalopex griseus) and the American mink (Neovison vison). Both predators were introduced in the island in the mid-1900s to control invasive rabbit populations (Jaksic and Yáñez 1983) and for the fur industry (Jaksic et al. 2002, Fasola et al. 2011), respectively. The gray fox is now the main nest predator of ground nests in the Fuegian steppe (Cossa 2019).

Sheldgeese could perceive livestock as a risk, like most wild animals do (Poudel et al. 2016), or be disturbed by livestock movement (Cossa et al. 2018) and so, be more alert at or avoid areas with livestock presence. An increase in the time allocated to vigilance at the expense of time spent in other activities, like foraging or mating, could have implications for their energy budget (Bélanger and Bédard 1990, Riddington et al. 1996, Houston et al. 2012, Christiansen et al. 2013) or even deter reproductive attempts. By contrast, sheldgeese could receive benefits from livestock by sharing vigilance with them, as they do through foraging in mixed-species flocks of sheldgeese (Canevari 1996). They may benefit from foraging in groups, for example, if group probability of detecting a predator increases or if the individual spends less time in vigilance allowing more time for other activities (Pulliam 1973, Lazarus 1978, Lima 1995, Amano et al. 2006). Thus, different combinations of group and individual vigilance could occur, in which group and individual vigilance increases, decreases, or remains constant (Fernández et al. 2003). Mixed species foraging associations, as the one that could be happening between sheldgeese and cattle, are documented for birds, primates, fishes, and mongooses, among others (Morse 1977, Sullivan 1984, Terborgh 1990, Noë and Bshary 1997, McGraw and Bshary 2002, Goodale and Kotagama 2005, Sharpe et al. 2010). Consequently, livestock presence could affect sheldgeese use of foraging and nesting sites and foraging and reproductive behavior.

A previous study has found that livestock were responsible for at least $3 \%$ of sheldgeese nest losses because of trampling and caused disturbance to $14 \%$ of breeding pairs (Cossa et al. 2018). Exclusion of livestock using wire fences, protection boxes, or electric fences is one of the conservation actions used worldwide to increase reproductive success of bird species threatened by livestock (Moore 2005, Pauliny et al. 2008, among others). The cues used when choosing sites for reproduction are not necessarily the same as when choosing sites for foraging. Therefore, interactions of sheldgeese foraging flocks with livestock should not necessarily be the same as those of sheldgeese breeding pairs with livestock.
The study of the interactions between sheldgeese and livestock is relevant for sheldgeese conservation and management because changes in their behavior as a result of those interactions could have implications for their fitness, by reducing their energy budget resulting in low body condition (Houston et al. 2012, Christiansen et al. 2013). Upland Goose females with higher body condition lay bigger eggs and clutches; moreover, body condition of chicks from females with high body condition is higher compared to chicks of low body condition females (Gladbach et al. 2010). Also, because livestock farming continues to be one of the main economic activities throughout sheldgeese breeding areas, the interaction between wildlife populations and livestock will continue. Thus, it is important to characterize these interactions and their conservation implications to find management actions that could reduce the conflict between wildlife conservation and productive activities.

Our broad objective was to better understand associations between sheldgeese and livestock. We described direct interactions between livestock and sheldgeese by comparing the use of sites and behavior of sheldgeese in relation to the presence/ absence of livestock. We hypothesized that sheldgeese incur costs associating with livestock in foraging groups through an increase in time devoted to vigilance. Alternatively, sheldgeese might obtain benefits by associating with livestock and sheldgeese would then dedicate less or equal time to vigilance than in the absence of livestock. For breeding pairs, we also explored site use with regard to livestock presence. As livestock caused nest failures (Cossa et al. 2018), we expected breeding pairs to segregate from livestock during spring and summer. Furthermore, we explored nest success in areas experimentally closed to livestock as a way to test the effect of a direct management action that could improve sheldgeese reproductive success.

\section{METHODS}

\section{Study area}

We conducted field work in two separate study areas. Study area 1 was located in the southern Santa Cruz Province (south of latitude $51^{\circ} 38^{\prime} 42^{\prime \prime} \mathrm{S}$ ) and the northern part of the main island of Tierra del Fuego Province (north of latitude $54^{\circ} 7^{\prime} 48^{\prime \prime} \mathrm{S}$ ). This is one of the main sheldgeese reproductive areas and it is almost the only reproductive area of the Ruddy-headed Goose in Argentina, the most threatened species of the group (Cossa et al. 2017, MAyDS and AA 2017). This area is covered by Magellanic steppe, dominated by tussock grasslands, mainly Festuca gracillima, associated with bushy vegetation in varying percentages. Lowland parts are associated with shallow lakes, streams, or temporary flooded areas called vegas or mallines in which other grasses (Deschampsia antarctica, Hordeum halophilum, Festuca magellanica) as well as rushes and Carex spp. dominate (Madsen et al. 2003, Petracci et al. 2014). Study area 2 was in northwestern Santa Cruz Province, Argentina (46 $37^{\prime} 48^{\prime \prime}$ $\mathrm{S}-47^{\circ} 15^{\prime} 54^{\prime \prime} \mathrm{S}, 71^{\circ} 49^{\prime} 30^{\prime \prime} \mathrm{W}-70^{\circ} 24^{\prime} 18^{\prime \prime} \mathrm{W}$ ), near Patagonia National Park. This area has a high density of Upland Goose nests, whereas the Ashy-headed Goose is rare and the Ruddyheaded Goose is absent. Predominant habitat type is Patagonia steppe, dominated by bushy vegetation, such as Chuquiraga avellanedae, Nassauvia glomerulosa, Stipa humilis, Stipa neaei, Stipa speciosa, Ameghinoa patagonica, Nardophyllum obtusifolium, and Brachyclados caespitosus, associated with grasses and low 
herbaceous dicotyledons. Lowland areas are dominated by grasses (Cabrera 1971). In both study areas, the main human activity is livestock farming, and as such, most of the land is being used by livestock, which are raised in large (usually 5000+ hectares) fields. Livestock includes sheep, cows, and horses and their density and distribution varies between farms.

\section{Data collection}

\section{Site use by sheldgeese flocks and breeding pairs}

In study area 1, every season between 2013 and 2016, two observers performed road-based surveys using the line transect census technique (Bibby et al. 1992). At each survey, we covered as much of the area as possible driving along all main (national and provincial public routes) and secondary (private) roads at a speed of $40-60 \mathrm{~km} / \mathrm{h}$ to maximize visibility of birds. We recorded the number of sheldgeese observed using $8 \times 32$ and $10 \times 42$ binoculars, and a 20-60 x spotting scope along a strip of $500 \mathrm{~m}$ on both sides of the road. This strip is effective for spotting sheldgeese given the open nature of the steppe environment and the size of the species (60-65 cm; Martín 1984, Petracci et al. 2013, 2014, 2015b). We assumed that we detected all the individuals present in the area covered. A possible shortcoming of roadside surveys is the lower detection in high vegetation patches. However, high vegetation patches are scarce, and this is a methodological bias shared with most previous sheldgeese surveys in Patagonia (Petracciet al. 2013, 2014, 2015b). In the case of the Upland Goose (the only clearly sexually dimorphic one of the three species), we registered the presence of breeding pairs. If livestock were detected nearby (within a $100 \mathrm{~m}$ radius) a sheldgeese flock or an Upland Goose couple, we recorded the number and distribution of individuals (within or at the periphery of the flock). When livestock were detected further than $100 \mathrm{~m}$ radius, we considered that sheldgeese were not associated with the livestock. We surveyed $794 \mathrm{~km}$ in spring 2013, $580 \mathrm{~km}$ in summer 2014, $466 \mathrm{~km}$ in autumn 2014, $184 \mathrm{~km}$ in winter 2014, $618 \mathrm{~km}$ in spring 2014, $811 \mathrm{~km}$ in summer 2015, $614 \mathrm{~km}$ in autumn, $242 \mathrm{~km}$ in winter 2015 , and $564 \mathrm{~km}$ in summer 2016. Population numbers fluctuate throughout the year (Cossa 2019). Spring (September to December) is the season in which breeding attempts occur and in summer (December to March), the successful breeding attempts can be assessed. In autumn (March to June), big groups gather before migration to wintering areas and in winter (June to September), individuals who do not migrate can be censused (c. $20 \%$ of the autumn numbers; Cossa 2019).

\section{Livestock influence on sheldgeese behavior}

During surveys in Tierra del Fuego (within study area 1), we located sheldgeese flocks of more than 10 individuals that were far from $(>500 \mathrm{~m}, n=14)$ and close to $(<100 \mathrm{~m}, n=14)$ livestock. Mean flock sizes with and without livestock were 58.21 \pm 9.67 and $59.71 \pm 8.85$, respectively. We assumed that all three species react similarly to different livestock species (sheep, cattle, and/or horses). As noted before, we assumed that livestock do not affect sheldgeese behavior if they are far away and hence we did not consider an association. We chose flocks opportunistically and maintained a balanced number of flocks per habitat types (scrub, meadow, or grass lawns) and with respect to livestock (associated or not), thus avoiding our results being masked by an association between each behavior and habitat characteristics. We also alternated the order of our observations between flocks with and without livestock. Using a 20-60 x spotting scope 30-100 m away and from a vehicle, we observed each flock and determined the total number of individuals, species, and sex in the case of the Upland Goose. We waited until all individuals in a flock resumed normal behaviors before starting observations. The area is highly transited by vehicles, so sheldgeese are quite used to them. We recorded sheldgeese behavior using two methods (Altmann 1974). First, we scanned the flock and recorded the instantaneous behavior of all individuals (number of individuals in each behavior category). Second, in those flocks where there were Upland Goose individuals, we examined by focal sampling the time spent on each behavior category by one random female and one random male because several studies have found sex differences in the time allocated to vigilance (e.g., White-fronted Geese Anser albifrons, Fox et al. 1995; Greater Rhea Rhea americana Reboreda and Fernandez 1997; Coal-crested Finch Charitospiza eucosma, Diniz 2011; Eurasian Skylark Alauda arvensis, Powolny et al. 2014). Focal sampling of each individual lasted 15 minutes. Behavior categories were: vigilance (head up on alert posture, even between feeding bouts), foraging (head down cropping the grass or drinking water), resting (standing or sitting with the neck folded and head on shoulder, simply laying down, or preening), and walking (with the head up). Other behaviors occurred infrequently (e.g., $<5 \%$ of the observed time or the individuals in a flock) and were discarded.

\section{Livestock influence on sheldgeese nesting}

We examined the influence of livestock on daily survival rate of nests using both an observational and an experimental approach. We monitored Upland Goose nests in study area 2 from early November to late December of 2015 and 2017. The Upland Goose builds its nests on the ground close to water $(\leq 500 \mathrm{~m}$ approximately), along river valleys, around ponds, and along the seacoast (Summers 1983). Because territories are defended by the male while the female carries out the incubation (Summers 1983), we searched for nests by focusing on solitary male activity and inspecting potential nesting sites. Nests were found at different stages during laying and incubation. Additionally, during the 2017 season, we built an exclosure of 8 ha $(200 \times 400 \mathrm{~m})$ with electric poly wires to exclude livestock from nests. The electric fence consisted of two electrified poly wires at $50 \mathrm{~cm}$ and $90 \mathrm{~cm}$ above the ground. The fence produced a pulsed energy output of $0.75 \mathrm{~J}$ and was solar powered. The exclosure area was selected based on a previous exhaustive nest search and we aimed to include as many nests as possible within it. We used camera traps to monitor 35 nests in 2015 (no exclosure) and 52 nests in 2017 (10 inside and 42 outside the exclosure). Nests were monitored from when they were detected until the chicks hatched or the nest was depredated or deserted (e.g., after trampling). In all cases, cameras were tied to $40 \mathrm{~cm}$ stakes placed $5 \mathrm{~m}$ away from the nest and set up to take a picture (Bushnell HD Essential and Reconix PC800 models) or a picture and a 10 second video (Bushnell HD max) when detecting movement. We used 10-second intervals between detections and set the sensor level to automatic. Nests were revisited every seven days to monitor nest contents and to check the battery charge and available space on the memory card of the camera.

\section{Data analyses}

We analyzed whether flock size varied between the presence and absence of livestock performing a $t$-test (Student 1908). For 
behavior observations, we performed Dirichlet regressions models, which can be used to analyze a set of variables lying in a bounded interval that sum up to a constant (compositional data, e.g., proportions; Maier 2014). We ran three models, one for scan sampling and two for focal sampling observations, one for females and another for males. The four behavior categories were the dependent variables whereas presence of livestock and flock size were the independent variables, because vigilance behavior can vary with group size like in most animals (Lima and Dill 1990, Roberts 1996 for reviews).

We estimated the daily survival rate (DSR) of nests using RMark (White and Burnham 1999, Laake et al. 2013) from the information recovered with camera traps. We first estimated the DSR for nests without exclosure (all of 2015 and the 2017 nests located outside the exclosure, 59 nests in total). For this, we analyzed seven competing models, which are all possible combinations from the null model (no explanatory/effect variable) to models including one, two, or three fixed effects. One fixed effect was livestock proximity, which is the cumulative time livestock remained in the proximity of the nest $(<5 \mathrm{~m}$ from the nest) divided by monitored time. Another fixed effect was livestock disturbance, which is the number of disturbances (the incubating female forced to leave the nest) caused by livestock divided by monitored time. The third fixed effect was the year. We compared the models to test the effect of livestock and year. To test the effect of protecting nests using an electric fence, we estimated the DSR for all 2017 nests (inside and outside the exclosure) with two models that were then compared: null model (no exclosure effect) and one that included the exclosure effect, which considered whether the nest was inside the exclosure or not.

All statistical analyses were carried out using R 4.0.0 (R Core Team 2020). We used DirichletReg 0.6-4 (Maier 2014), and RMark 2.2.2 (White and Burnham 1999, Laake et al. 2013) R packages. All tests were two tailed; values are reported as means $\pm \mathrm{SE}$ and differences were considered significant at $P<0.05$. We report Cohen's effect ( $d$; Cohen 1988). Cohen defined effect sizes as "small, $d=0.2$, " "medium, $d=0.5$," and "large, $d=0.8$." For sheldgeese nesting analyses, model selection was based on information-theoretic procedures (Burnham and Anderson 2004) comparing AICc values. The best model was that with the lowest AICc (Burnham and Anderson 1998).

\section{RESULTS}

\section{Sheldgeese foraging flocks and livestock}

\section{Site use}

We registered 74,256 sheldgeese in 3286 sightings with 102 sightings of solitary individuals, 788 of Upland Goose breeding pairs, and 2396 sightings of flocks (flock size $=30.58 \pm 1.20$, range $=3-1069)$. The proportion of flocks with the three species was $1.3 \%$ (31 flocks) and 16.4\% had two species (364 Upland and Ashy-headed Goose mixed flocks, 28 Upland and Ruddy-headed Goose mixed flocks). The remaining groups (82.3\%) were monospecific (1926 Upland Goose flocks, 33 Ashy-headed Goose flocks, and 14 Ruddy-headed Goose flocks). The Upland Goose was present in $98 \%$ of the flocks, the Ashy-headed Goose in 18\% of the flocks, and the Ruddy-headed Goose in only 3\% of the flocks. Sheldgeese flocks were more frequently sighted alone than associated with livestock and flock size was smaller in absence than in presence of livestock $(26.41 \pm 1.15, \mathrm{n}=1788$ vs. 43.33 $\pm 3.3, \mathrm{n}=585, t=-6.1, P<0.001, d=0.26)$. In the $12 \%$ of the sightings with livestock, livestock were interspersed (mixed) with sheldgeese (70 sightings, 3453 sheldgeese).

\section{Sheldgeese behavior}

Livestock presence affected sheldgeese behavior both for scan $(P$ $=0.001)$ and focal $\left(P_{\text {females }}=0.009, P_{\text {males }}<0.001\right)$ observations, and flock size was not significant $\left(P_{\text {scan }}=0.28, P_{\text {females }}=0.76\right.$, $\left.P_{\text {males }}=0.47\right)$. The proportion of individuals resting was lower in the presence of livestock (Table 1, Fig. 1). There was no difference in the proportion of individuals in a flock foraging, vigilant, or walking. Foraging was the most prevalent behavioral activity both without livestock (49\% of individuals) and with livestock $(69 \%)$.

Table 1. Dirichlet Regressions estimates \pm SE, $z$ values and significance $(\mathrm{P})$ of the predictor variables on the proportion of sheldgeese individuals conducting different behaviors from scan sampling observations performed in 2013-2016 in Patagonia, Argentina. Number of flocks $=28$ (14 without livestock and 14 with livestock).

\begin{tabular}{|c|c|c|c|}
\hline & Estimate $\pm \mathrm{SE}$ & $\bar{z}$ & $P$ \\
\hline \multicolumn{4}{|l|}{ Vigilance } \\
\hline Intercept & $0.25 \pm 0.25$ & 0.98 & 0.32 \\
\hline Livestock & $-0.05 \pm 0.36$ & -0.14 & 0.89 \\
\hline \multicolumn{4}{|l|}{ Foraging present } \\
\hline Intercept & $1.28 \pm 0.25$ & 5.16 & $<0.001 *$ \\
\hline Livestock & $0.45 \pm 0.35$ & 1.28 & 0.2 \\
\hline \multicolumn{4}{|l|}{ Resting present } \\
\hline Intercept & $0.77 \pm 0.25$ & 3.09 & $0.002 *$ \\
\hline Livestock $_{\text {present }}$ & $-0.99 \pm 0.36$ & -2.75 & $0.006 *$ \\
\hline \multicolumn{4}{|l|}{ Walking present } \\
\hline Intercept & $-0.31 \pm 0.26$ & -1.22 & 0.22 \\
\hline Livestock $_{\text {present }}$ & $0.11 \pm 00.36$ & 0.31 & 0.76 \\
\hline
\end{tabular}

Fig. 1. Box plots of the proportion of sheldgeese individuals performing different behaviors in flocks without (14 flocks) and with (14 flocks) livestock. Data were collected using scan sampling technique from spring 2013 to summer 2016 in Patagonia, Argentina. * Indicates significant influences $(\mathrm{P}<$ $0.05)$ evaluated with a Dirichlet Regressions model. Crosses indicate means. $d=$ Cohen's effect size.

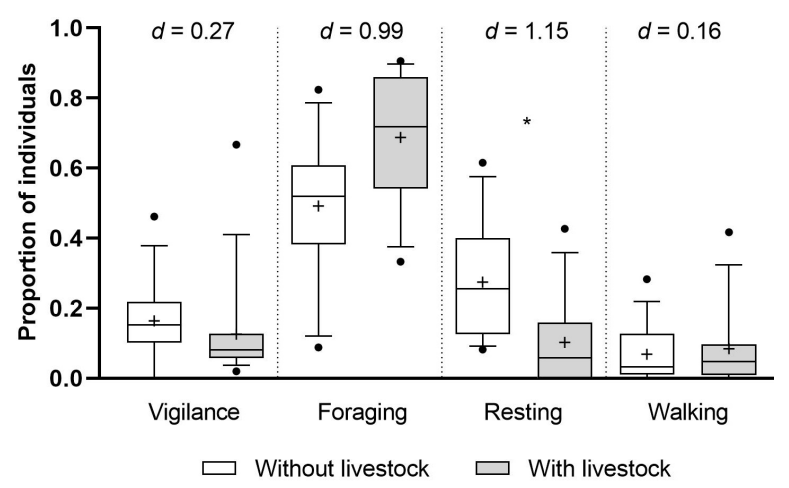


Table 2. Dirichlet Regressions estimates $\pm \mathrm{SE}, \mathrm{z}$ values and significance $(\mathrm{P})$ of the predictor variables on the proportion of time allocated by Upland Goose females and males to different behaviors from focal sampling observations performed in 2013-2016 in Patagonia, Argentina. Number of individuals $=56$ (28 females and 28 males).

\begin{tabular}{|c|c|c|c|c|c|c|}
\hline & \multicolumn{2}{|c|}{ Estimate $\pm \mathrm{SE}$} & \multicolumn{2}{|c|}{$\mathrm{z}$} & \multicolumn{2}{|c|}{$P$} \\
\hline & Females & Males & Females & Males & Females & Males \\
\hline \multicolumn{7}{|l|}{ Vigilance } \\
\hline Intercept & $-0.39 \pm 0.26$ & $-0.67 \pm 0.26$ & -1.53 & -2.6 & 0.13 & $0.009^{*}$ \\
\hline Livestock & $0.55 \pm 0.36$ & $0.92 \pm 0.36$ & 1.51 & 2.54 & 0.13 & $0.01 *$ \\
\hline \multicolumn{7}{|l|}{ Foraging present } \\
\hline Intercept & $0.36 \pm 0.26$ & $0.5 \pm 0.26$ & 1.39 & 1.9 & 0.16 & 0.06 \\
\hline Livestock $_{\text {present }}$ & $1.35 \pm 0.36$ & $1.44 \pm 0.36$ & 3.71 & 3.94 & $<0.001 *$ & $<0.001^{*}$ \\
\hline \multicolumn{7}{|l|}{ Resting } \\
\hline Intercept & $-0.48 \pm 0.26$ & $-0.12 \pm 0.26$ & -1.88 & -0.46 & 0.06 & 0.64 \\
\hline Livestock & $0.21 \pm 0.36$ & $-0.16 \pm 0.37$ & 0.58 & -0.43 & 0.56 & 0.67 \\
\hline \multicolumn{7}{|l|}{ Walking present } \\
\hline Intercept & $-0.73 \pm 0.26$ & $-0.9 \pm 0.26$ & -2.84 & -3.49 & $0.004 *$ & $<0.001^{*}$ \\
\hline Livestock $_{\text {present }}$ & $0.51 \pm 0.36$ & $0.69 \pm 0.36$ & 1.41 & 1.9 & 0.16 & 0.06 \\
\hline
\end{tabular}

The proportion of time that individuals allocated to foraging (for both sexes) and to vigilance (for males) was higher in the presence of livestock (Table 2, Fig. 2). There were no differences in the time allocated to rest and walk (for both sexes) and for vigilance (for females) regarding livestock presence.

\section{Sheldgeese breeding pairs and livestock}

\section{Site use}

As with foraging flocks, nearly all breeding pairs of Upland Goose were observed in fields without livestock (626 of 788 observations $(79.4 \%))$.

\section{Sheldgeese nesting}

The effective number of monitored nests (nests for which we could determine if they were successful or not by analyzing pictures and videos) was 26 in 2015 (without enclosure) and 42 in 2017 (9 inside the exclosure and 33 outside). Of the 59 nests monitored without an exclosure, only 12 hatched (at least 1 chick). Thirty-seven were depredated ( 36 by foxes and 1 by a Kelp Gull Larus dominicanus), 2 were lost due to trampling ( 1 by cows and 1 by horses), 2 failed due to undetermined reasons, and 6 were abandoned. Two nests were abandoned presumably due to the camera trap, two to territory competition with another Upland Goose couple, one to the inspection of the nest by a family of pumas Puma concolor (Cossa et al. 2020a), and one due to livestock disturbances. Of the nine nests monitored inside the exclosure, six hatched, two were depredated by foxes, and one failed due to undetermined reasons. The best model (Table 3) indicates that the DSR was negatively affected by the frequency of livestock disturbances and that the DSR was higher in 2015 . However, $95 \%$ credible interval of livestock disturbances included zero (Intercept: $1.86 \pm 0.21$ [1.45-2.28], Disturbances: -46.55 \pm 26.19 [-97.89-4.79], Year $_{2015}$ : $1.15 \pm 0.34[0.48-1.81])$. Finally, the use of an electric fence was effective in protecting nests (Table 4). Nests protected from livestock showed a higher DSR than unprotected nests $(0.97$ \pm 0.02 vs. $0.87 \pm 0.02, d=1.13$, Intercept: $3.43 \pm 0.51$ [2.43-4.43] Enclosure $\left._{\text {no-protected }}:-1.55 \pm 0.55[-2.63-0.47]\right)$. The probability of a nest surviving in the presence of livestock through to the end of the incubation period ( 30 days) was almost zero. If nests were protected from livestock, the probability increases to $40 \%$ (Fig. 3).

Fig. 2. Proportion of time Upland Goose females (28, up) and males (28, down) allocated to different behaviors in flocks without (14 flocks) and with (14 flocks) livestock. Data were collected using focal sampling technique from spring 2013 to summer 2016 in Patagonia, Argentina. * Indicates significant influences $(\mathrm{P}<0.05)$ evaluated with Dirichlet Regressions models. Crosses indicate means. $d=$ Cohen's effect size.
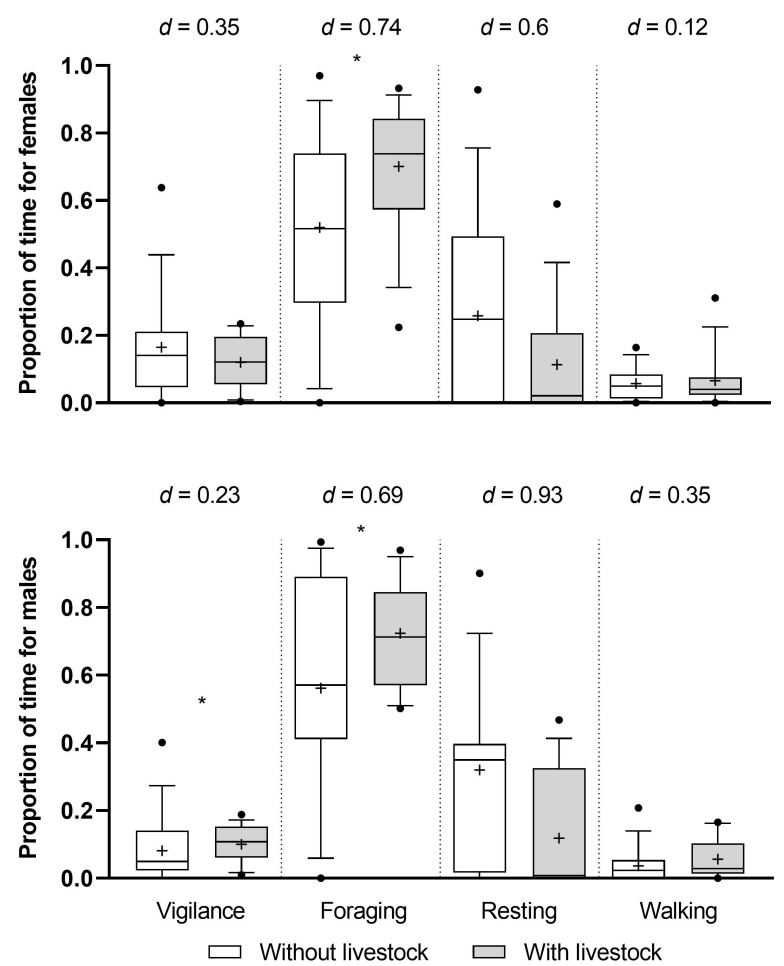
Table 3. Model comparison for daily survival rates for Upland Goose nests exposed to livestock in 2015 and 2017 in Patagonia, Argentina. Proximity: cumulative time livestock remained in the proximity of the nest. Disturbance: number of times livestock forced the incubating female to leave the nest. Number of nests $=59$.

\begin{tabular}{lcccc}
\hline \hline Model & $\begin{array}{c}\mathrm{N}^{\mathrm{o}} \\
\text { parameters }\end{array}$ & $\Delta \mathrm{AICc}^{\dagger}$ & Weight & Deviance \\
\hline Disturbances + Year & 3 & 0 & 0.61 & 214.05 \\
Disturbances + Proximity + Year & 4 & 1.92 & 0.23 & 213.94 \\
Year & 2 & 3.47 & 0.11 & 219.55 \\
Proximity + Year & 3 & 5.41 & 0.04 & 219.46 \\
Disturbances & 2 & 10.48 & 0.003 & 226.55 \\
Null & 1 & 11.89 & 0.002 & 229.99 \\
Disturbances + Proximity & 3 & 12.38 & 0.001 & 226.43 \\
Proximity & 2 & 13.79 & $<0.001$ & 229.87 \\
\hline
\end{tabular}

Lowest AICc $=220.10$

Table 4. Model comparison for daily survival rates for Upland Goose nests exposed and protected from livestock in 2017 in Patagonia, Argentina. Number of nests $=42$.

\begin{tabular}{lcccc}
\hline \hline Model & $\begin{array}{c}\mathrm{N}^{\circ} \\
\text { parameters }\end{array}$ & $\Delta$ AICc $^{\dagger}$ & Weight & Deviance \\
\hline Enclosure & 2 & 0 & 0.99 & 143.18 \\
Null & 1 & 8.79 & 0.01 & 153.99 \\
\hline
\end{tabular}

${ }^{\circ}$ Lowest AICc $=147.22$

Fig. 3. Cumulative probability of survival of Upland Geese nests along the incubation. Data correspond to nests protected from livestock using an electric fence and nest exposed to livestock during 2015 and 2017 breeding seasons in Patagonia, Argentina. Cumulative probability was calculated as the mean daily survival rate raised to power of number of days of incubation.

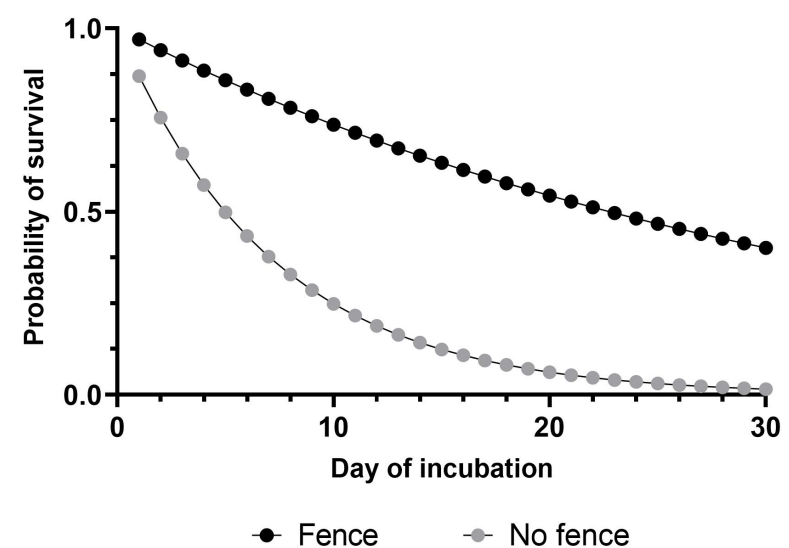

\section{DISCUSSION}

Sheldgeese flocks and breeding pairs were more frequently sighted away from livestock. Our results do not support the hypothesis that sheldgeese receive benefits in reduced time spent in vigilance, from being close to livestock because we did not detect a decrease in vigilance. At the group level, there were fewer individuals resting in livestock presence than in their absence. At the individual level, both females and males allocated more time to foraging and males more time to vigilance in livestock presence than in their absence. Finally, protection of nesting sites with electric fences to exclude livestock should be considered as a management option to favor sheldgeese local reproduction because nests protected from livestock had higher daily survival rates than unprotected ones.

We did not find a positive association between the occurrence of sheldgeese flocks and livestock. Although livestock do not move freely in space and depend on the distribution scheduled by land managers, livestock are raised in large fields that include different vegetation patches. Within each field, livestock is free to move between the different habitat types and to stop at the preferred one. This preferred habitat could be the same for both livestock and sheldgeese, thus livestock and sheldgeese could be selecting the most productive habitats within large fields. This could explain the presence of sheldgeese flocks foraging alongside livestock and why they spent more time foraging when associated with livestock.

Different studies have shown that livestock can modify the behavior of wild animals. For example, the Himalayan marmot (Marmota himalayana) scanned the surroundings more often and spent more time scanning in highly grazed areas compared to marmots in lesser grazed areas, and they also shifted the time of day to forage in those highly grazed areas to avoid livestock (Poudel et al. 2016). When sheldgeese foraged alongside livestock, there were fewer individuals resting and sheldgeese allocated more time to foraging. These results indicate that sheldgeese behave differently in the presence of livestock. This could be the result of physical disturbance by livestock (i.e., sheldgeese move around as a result of livestock movement and therefore they rest less and forage more because sheldgeese walk while foraging).

We did not find a benefit in terms of a decrease in individual vigilance in sheldgeese flocks sharing foraging patches with livestock. Moreover, males allocated more time to vigilance in the presence of livestock. However, without decreasing individual vigilance, sheldgeese could still benefit from the presence of livestock by an increase in total vigilance. Adult sheldgeese predators in Tierra del Fuego are scarce. Foxes mainly prey on nests, goslings, and, in some instances, on the incubating female (N. Cossa, L. Fasola, I. Roesler, and J Reboreda, unpublished data). Moreover, sheldgeese flocks do not get alarmed in the presence of foxes (we saw foxes walking through sheldgeese flocks and they did not flee). They do get alarmed (look up) in the presence of raptors such as Black-chested Buzzard-Eagles (Geranoaetus melanoleucus), which depredate sheldgeese adults (Cossa et al. 2020b). Although livestock are not affected by these predators, sheldgeese and livestock are both affected by humans and vehicles and could be getting the benefit of, in this case, increased probability of detecting those risks. 
Upland Goose breeding pairs were also more frequently sighted alone than associated with livestock. Moreover, nests protected from livestock had higher daily survival rates than unprotected ones, though this result should be taken with precaution because of the low sample size of nests in exclosures. Although the main cause of failure of unprotected nests was fox depredation, during incubation sheldgeese females were often disturbed by livestock, which resulted in them abandoning the nest for variable periods of time (Cossa et al. 2018). This increase in activity and movement around the nest could have increased the nest detectability by predators, although our models failed to accurately detect this effect, possibly because of the small sample size. Another factor that could have affected nest detectability is vegetation cover. Thicker vegetation cover due to reduced livestock grazing could make nests less visible to predators. We also found differences in the DSR between years, which could be due to climate interannual variations or to different predator management by landowners. We are extending the investigation of the mechanism related to the increase in the reproductive success in fields without livestock.

Sheldgeese flocks and breeding pairs were negatively associated with livestock and, moreover, we found that the presence of livestock affected the behavior and the reproductive success of sheldgeese to some degree. Predator management is much more expensive and logistically complex than livestock exclusion, which can be achieved with relatively low costs because livestock is managed by man. We consider that the use of this type of exclusion can be a management action that favors sheldgeese reproduction while we evaluate possibilities to reduce predation, which is the main cause of nest failure. Though, one important conservation action should be to identify those areas that concentrate a great number of breeding pairs and protect them from livestock at the peak of the reproductive season (when there is a high simultaneous number of active nests in the spring). In addition, for areas that are repeatedly used as breeding sites, it would be advantageous to protect them from the beginning of the reproductive season to favor vegetation cover, increasing the concealment of future nests. Studies that assess the time it takes vegetation to recover will help to decide the appropriate time to protect the areas, without the need to protect them throughout the whole year. One way to achieve this could be through government or conservation agency subsidies for landowners to exclude or reduce livestock numbers of important sheldgeese breeding areas. Another likely conservation action could be the construction of small artificial nest islets. This action, different from the construction of electric fences, has the advantage of protecting nests from livestock and predators. Moreover, construction of islands would probably conflict less with landowners because they would not need to change their land management practices.

Responses to this article can be read online at: http://www.ace-eco.org/issues/responses.php/1630

\section{Acknowledgments:}

The fieldwork in Tierra del Fuego was supported by Neotropical Grassland Conservancy, CREOi, and Becas Conservar la Argentina from Aves Argentinas/AOP. In Santa Cruz, it was funded by Aves Argentinas/AOP, Tasso Leventis Foundation, Toyota Argentina, Servicios Públicos (Santa Cruz), Secretaría de Ambiente (Santa Cruz), Fundación Flora y Fauna Argentina, Pan American Energy, and Idea Wild. We thank the owners of Sara, Cullen, Los Flamencos, María Behety, La Vizcaína, El Rinción, El Unco, Telken, Casa de Piedra, El Milagro, La Paloma, and Laurak Bat ranches. We thank G. Montero, S. Imberti, P. Irazoqui, and E. Tiberi from Asociación Ambiente Sur; M. L. Carranza, M. L. Flotron, E. Curto, and D. Valenzuela from Dirección General de Áreas Protegidas y Biodiversidad of Tierra del Fuego; Consejo Agrario Provincial of Santa Cruz; T. Barreto and A. Ramos from Museo Municipal de Río Grande "Virginia Choquintel"; S. Alvarado from Agencia Ambiental Municipal de Río Gallegos; J. L Hormaechea, G. Connon, and L. Barbero from Estación Astronómica Río Grande; A. Gorosabel; M. L. Marcías; Pietrek family; and Proyecto Macá Tobiano volunteers. We also thank two anonymous reviewers and Lucía Babino who provided their helpful comments on a previous version of the manuscript. NC was supported by a doctoral studentship from the Consejo Nacional de Investigaciones Cientificas y Técnicas (CONICET). This is publication \#20 of the Patagonia Program.

\section{LITERATURE CITED}

Aagesen, D. 2000. Crisis and conservation at the end of the world: sheep ranching in Argentine Patagonia. Environmental Conservation 27:208-215. https://doi.org/10.1017/S0376892900000229

Altmann, J. 1974. Observational study of behavior: sampling methods. Behaviour 49:227-266. https://doi.org/10.1163/156853974X00534

Amano, T., K. Ushiyama, G. Fujita, and H. Higuchi. 2006. Costs and benefits of flocking in foraging white-fronted geese (Anser albifrons): effects of resource depletion. Journal of Zoology 269:111-115. https://doi.org/10.1111/j.1469-7998.2006.00076.x

Bélanger, L., and J. Bédard. 1990. Energetic cost of man-induced disturbance to staging Snow Geese. Journal of Wildlife Management 54:36-41. https://doi.org/10.2307/3808897

Bibby, C. J., N. D. Burgess, and D. A. Hill. 1992. Bird census techniques. Academic Press, London, UK.

BirdLife International. 2020. IUCN red list for birds. BirdLife International, Cambridge, UK. [online] URL: http://datazone. birdlife.org/home

Burnham, K. P., and D. R. Anderson. 1998. Model selection and inference. Springer, New York, New York, USA. https://doi. org/10.1007/978-1-4757-2917-7

Burnham, K. P., and D. R. Anderson. 2004. Multimodel inference: understanding AIC and BIC in model selection. Multimodel inference. Sociological Methods and Research 33:261-304. https://doi.org/10.1177/0049124104268644

Cabrera, A. L. 1971. Fitogeografía de la República Argentina. Boletín de La Sociedad Argentina de Botánica 14:1-42.

Canevari, P. 1996. The Austral geese (Chloephaga spp.) of southern Argentina and Chile: a review of its current status. Gibier Faune Sauvage 13:355-366. 
Christiansen, F., M. H. Rasmussen, and D. Lusseau. 2013. Inferring activity budgets in wild animals to estimate the consequences of disturbances. Behavioral Ecology 24:1415-1425. https://doi.org/10.1093/beheco/art086

Cohen, J. 1988. Statistical power analysis for the behavioral sciences. Second Edition. Lawrence Earlbaum, Hillsdale, Michigan, USA. https://doi.org/10.4324/9780203771587

Cossa, N. A. 2019. Biología de la conservación de tres especies de cauquén (Chloephaga spp.). Dissertation. Universidad de Buenos Aires, Buenos Aires, Argentina.

Cossa, N. A., L. Fasola, I. Roesler, and J. C. Reboreda. 2017. Ruddy-headed Goose Chloephaga rubidiceps: former plague and present protected species on the edge of extinction. Bird Conservation International 27:269-281. https://doi.org/10.1017/ S0959270916000101

Cossa, N. A., L. Fasola, I. Roesler, and J. C. Reboreda. 2018. Incubating Upland Goose (Chloephaga picta) differential response to livestock, human, and predator nest disturbance. Wilson Journal of Ornithology 130:739-745. https://doi. org/10.1676/17-105.1

Cossa, N. A., M. S. Malerba, L. Fasola, and I. Roesler. $2020 a$. Pumas (Puma concolor) en un nido de cauquén común (Chloephaga picta). Notas Sobre Mamíferos Sudamericanos.

Cossa, N. A, M. Pendaries, M. L. Flotron, L. Martín, S. Ovando, and M. L. Carranza. 2020b. Águila Mora (Geranoaetus melanoleucus) depredando cauquenes comunes (Chloephaga picta) adultos. Nuestras Aves, in press.

Diniz, P. 2011. Sex-dependent foraging effort and vigilance in coal-crested finches, Charitospiza eucosma (Aves: Emberizidae) during the breeding season: evidence of female-biased predation? Zoología 28:165-176. https://doi.org/10.1590/S1984-46702011000200003

Edwards, G. P., D. B. Croft, and T. J. Dawson. 1996. Competition between red kangaroo (Macropus rufus) and sheep (Ovis aries) in the arid rangelands of Australia. Australian Journal of Ecology 21:165-172. https://doi.org/10.1111/j.1442-9993.1996.tb00597.x

Fasola, L., J. Muzio, C. Chehébar, M. Cassini, and D. W. Macdonald. 2011. Range expansion and prey use of American mink in Argentinean Patagonia: dilemmas for conservation. European Journal of Wildlife Research 57:283-294. https://doi. org/10.1007/s10344-010-0425-6

Fernández, G. J., A. F. Capurro, and J. C. Reboreda. 2003. Effect of group size on individual and collective vigilance in Greater Rheas. Ethology 109:413-425. https://doi.org/10.1046/

j.1439-0310.2003.00887.x

Fleischner, T. L. 1994. Ecological costs of livestock grazing in western North America. Conservation Biology 8:629-644. https:// doi.org/10.1046/j.1523-1739.1994.08030629.x

Fox, A. D., H. Boyd, and R. G. Bromley. 1995. Mutual benefits of associations between breeding and non-breeding Whitefronted Geese Anser afbifions. Ibis 137:151-156. https://doi. org/10.1111/j.1474-919X.1995.tb03233.x

Gladbach, A., D. J. Gladbach, and P. Quillfeldt. 2010. Seasonal clutch size decline and individual variation in the timing of breeding are related to female body condition in a non-migratory species, the Upland Goose Chloephaga picta leucoptera. Journal of Ornithology 151:817-825. https://doi.org/10.1007/s10336-010-0518-8

Goodale, E., and S. W. Kotagama. 2005. Alarm calling in Sri Lankan mixed-species bird flocks. Auk 122:108-120. https://doi. org/10.1093/auk/122.1.108

Houston, A. I., E. Prosser, and E. Sans. 2012. The cost of disturbance: a waste of time and energy? Oikos 121:597-604. https://doi.org/10.1111/j.1600-0706.2011.19594.x

Hull, V., J. Zhang, S. Zhou, J. Huang, A. Viña, W. Liu, M.-N. Tuanmu, R. Li, D. Liu, W. Xu, Y. Huang, Z. Ouyang, H. Zhang, and J. Liu. 2014. Impact of livestock on giant pandas and their habitat. Journal for Nature Conservation 22:256-264. https://doi. org/10.1016/j.jnc.2014.02.003

Ibarra, J. T., L. Fasola, D. W. Macdonald, R. Rozzi, and C. Bonacic. 2009. Invasive American mink Mustela vison in wetlands of the Cape Horn Biosphere Reserve, southern Chile: what are they eating? Oryx 43:87-90. https://doi.org/10.1017/S0030605308099997

Instituto Nacional de Tecnología Agropecuaria (INTA). 2015. Situación actual y perspectiva de la ganadería en Patagonia [Current situation and perspective of livestock in Patagonia]. Technical report. Instituto Nacional de Tecnología Agropecuaria, Buenos Aires, Argentina. [online] URL: https://inta.gob.ar/ documentos/situacion-actual-y-perspectivas-de-la-ganaderia-enpatagonia-sur

Jaksic, F. M., J. A. Iriarte, J. E. Jiménez, and D. R. Martínez. 2002. Invaders without frontiers: cross-border invasions of exotic mammals. Biological Invasions 4:157-173. https://doi.org/10.1023/ A:1020576709964

Jaksic, F. M., and J. L. Yáñez. 1983. Rabbit and fox introductions in Tierra del Fuego: history and assessment of the attempts at biological control of the rabbit infestation. Biological Conservation 26:367-374. https://doi.org/10.1016/0006-3207(83) 90097-6

Kirsch, L. M. 1969. Waterfowl production in relation to grazing. Journal of Wildlife Management 33:821-828. https://doi. org/10.2307/3799313

Laake, J. L., D. S. Johnson, and P. B. Conn. 2013. marked: an R package for maximum likelihood and Markov Chain Monte Carlo analysis of capture-recapture data. Methods in Ecology and Evolution 4:885-890. https://doi.org/10.1111/2041-210X.12065

Lazarus, J. 1978. Vigilance, flock size and domain of danger size in the White-fronted Goose. Wildfowl 29:135-145. [online] URL: https://pdfs.semanticscholar.org/8857/23615edf9227dae20414f0fab84110ba6638.pdf

Lima, S. L. 1995. Back to the basics of anti-predatory vigilance: the group-size effect. Animal Behaviour 49:11-20. https://doi. org/10.1016/0003-3472(95)80149-9

Lima, S. L., and L. M. Dill. 1990. Behavioral decisions made under the risk of predation: a review and prospectus. Canadian Journal of Zoology 68:619-640. https://doi.org/10.1139/z90-092

Madsen, J., R. Matus, O. Blank, L. Benegas, G. Mateazzi, and D. E. Blanco. 2003. Population status of the Ruddy-headed Goose 
(Chloephaga rubidiceps) in Tierra del Fuego and mainland Patagonia (Chile and Argentina). Ornitología Neotropical 14:15-28.

Maier, M. J. 2014. DirichletReg: Dirichlet regression for compositional data in R. Research Report Series. Department of Statistics and Mathematics, WU Vienna University of Economics and Business, Vienna, Austria. [online] URL: http://epub.wu.ac. at $/ 4077 /$

Martín, S. 1984. La avutarda magallánica (Chloephaga picta) en la Patagonia: su ecología, alimentación, densidad y control. IDIA 2:429-432.

Ministerio de Ambiente y Desarrollo Sustentable and Aves Argentinas (MAyDS and AA). 2017. Categorización de las aves de la Argentina. Ministerio de Ambiente y Desarrollo Sustentable de la Nación y de Aves Argentinas, Buenos Aires, Argentina. [online] URL: https://avesargentinas.org.ar/sites/default/files/ Categorizacion-de-aves-de-la-Argentina.pdf

McGraw, W. S., and R. Bshary. 2002. Association of terrestrial mangabeys (Cercocebus atys) with arboreal monkeys: experimental evidence for the effects of reduced ground predator pressure on habitat use. International Journal of Primatology 23:311-325. https://doi.org/10.1023/A:1013883528244

Mishra, C., S. E. Van Wieren, P. Ketner, I. M. A. Heitkonig, and H. H. T. Prins. 2004. Competition between domestic livestock and wild bharal Pseudois nayaur in the Indian Trans-Himalaya. Journal of Applied Ecology 41:344-354. https://doi.org/10.1111/ j.0021-8901.2004.00885.x

Moore, P. 2005. Stock fencing and electric fence exclosures to prevent trampling of Chatham Island oystercatcher Haematopus chathamensis eggs, Chatham Island, New Zealand. Conservation Evidence 2:76-77. [online] URL: https://www.conservationevidence. com/individual-study/2166

Morse, D. H. 1977. Behavior and predator avoidance in heterospecific groups. BioScience 27:332-339. https://doi. org/10.2307/1297632

Noë, R., and R. Bshary. 1997. The formation of red colobus diana monkey associations under predation pressure from chimpanzees. Proceedings of the Royal Society B 264:253-259. https://doi.org/10.1098/rspb.1997.0036

Pauliny, A., M. Larsson, and D. Blomqvist. 2008. Nest predation management: effects on reproductive success in endangered shorebirds. Journal of Wildlife Management 72:1579-1583.

Petracci, P., M. E. Bravo, C. S. Lizarralde, M. L. Flotron, L. Fasola, N. Cossa, C. D. Amorós, S. A. Cadierno, and M. Amorós. 2014. Situación poblacional de los cauquenes (Chloephaga picta, C. poliocephala y C. rubidiceps) en las áreas reproductivas del extremo sur de la Patagonia Argentina, Temporada 2013-2014. Estrategia nacional para la conservación y el manejo del Cauquén Colorado, Cabeza Gris y Común en Argentina. Secretaría de Ambiente y Desarrollo Sustentable de la Nación, Buenos Aires, Argentina.

Petracci, P., M. L. Flotron, D. F. Valenzuela, N. Cossa, C. D. Amorós, and S. A. Cadierno. 2015b. Abundancia y distribución del Cauquén Común (Chloephaga picta), Cauquén Cabeza Gris
(C. poliocephala) y Cauquén Colorado (C. rubidiceps) en el extremo sur de la Patagonia Argentina. Estrategia nacional para la conservación y el manejo del Cauquén Colorado, Cabeza Gris y Común en la Argentina. Secretaría de Ambiente y Desarrollo Sustentable de la Nación, Buenos Aires, Argentina.

Petracci, P., H. Ibáñez, R. Baigún, J. Meriggi, J. Aguirre, M. E. Bravo, M. León, R. Sarria, J. Cereghetti, C. Klimaitis, M. Amorós, F. Hollmann, L. Albornoz, L. Banzato, M. Figueroa, P. Giovine, C. Vinci, M. Dolsan, R. Dosio, L. Grabosqui, P. Castro, A. Jones, S. Rivera, G. Herrera, A. Arias, M. Franco, M. Lisazu, R. Amado, C. Amorós, and S. Cadierno. 2015a. Monitoreo poblacional de cauquenes (Chloephaga sp.) en las provincias de Buenos Aires, La Pampa, Río Negro, Chubut y Santa Cruz. Reporte técnico, Temporada Julio 2014-2015. Estrategia nacional para la conservación y el manejo del Cauquén Colorado, Cabeza Gris y Común en Argentina. Secretaría de Ambiente y Desarrollo Sustentable de la Nación, Buenos Aires, Argentina.

Petracci, P., R. Sarria, F. Gaitán, and L. Fasola. 2013. Estatus poblacional de los cauquenes (Chloephaga sp.) en las áreas reproductivas del extremo sur de la Patagonia Argentina. Estrategia nacional para la conservación y el manejo del Cauquén Colorado, Cabeza Gris y Común en la Argentina. Secretaría de Ambiente y Desarrollo Sustentable de la Nación, Buenos Aires, Argentina.

Poudel, B. S., P. G. Spooner, and A. Matthews. 2016. Behavioural changes in marmots in relation to livestock grazing disturbance: an experimental test. European Journal of Wildlife Research 62:491-495. https://doi.org/10.1007/s10344-016-1014-0

Powolny, T., V. Bretagnolle, A. Aguilar, and C. Eraud. 2014. Sexrelated differences in the trade-off between foraging and vigilance in a granivorous forager. PLoS ONE 9:1-8. https://doi. org/10.1371/journal.pone.0101598

Prins, H. H. T. 2000. Competition between wildlife and livestock in Africa. Pages 51-80 in H. H. T. Prins, J. G. Grootenhuis, and T. T. Dolan, editors. Wildlife conservation by sustainable use. Kluwer Academic, Boston, Massachusetts, USA. https://doi. org/10.1007/978-94-011-4012-6_5

Pulliam, H. R. 1973. On the advantages of flocking. Journal of Theoretical Biology 38:419-422. https://doi.org/10.1016/0022-5193 (73)90184-7

R Core Team. 2020. R: a language and environment for statistical computing. R Foundation for Statistical Computing, Vienna, Austria. [online] URL: https://www.r-project.org/

Reboreda, J. C., and G. Fernandez. 1997. Sexual, seasonal and group size differences in the allocation of time between vigilance and feeding in the Greater Rhea. Ethology 103:198-207. https:// doi.org/10.1111/j.1439-0310.1997.tb00116.x

Riddington, R., M. Hassall, S. J. Lane, P. A. Turner, and R. Walters. 1996. The impact of disturbance on the behaviour and energy budgets of Brent Geese Branta b. bernicla. Bird Study 43:269-279. https://doi.org/10.1080/00063659609461019

Rindfuss, R. R., B. Entwisle, S. J. Walsh, L. An, N. Badenoch, D. G. Brown, P. Deadman, T. P. Evans, J. Fox, J. Geoghegan, M. Gutmann, M. Kelly, M. Linderman, J. Liu, G. P. Malanson, C. F. Mena, J. P. Messina, E. F. Moran, D. C. Parker, W. Parton, P. Prasartkul, D. T. Robinson, Y. Sawangdee, L. K. Vanwey, and P. 
H. Verburg. 2008. Land use change: complexity and comparisons. Journal of Land Use Science 31:1-10. https://doi. org/10.1080/17474230802047955

Roberts, G. 1996. Why individual vigilance declines as group size increases. Animal Behaviour 51:1077-1086. https://doi.org/10.1006/ anbe.1996.0109

Sharpe, L. L., A. S. Joustra, and M. I. Cherry. 2010. The presence of an avian co-forager reduces vigilance in a cooperative mammal. Biology Letters 6:475-477. https://doi.org/10.1098/rsbl.2009.1016

Student. 1908. The probable error of a mean. Biometrika 6:1-25. https://doi.org/10.2307/2331554

Sullivan, K. A. 1984. Information exploitation by downy woodpeckers in mixed-species flocks. Behaviour 91:294-311. https://doi.org/10.1163/156853984X00128

Summers, R. W. 1983. The life cycle of the Upland Goose Chloephaga picta in the Falkland Islands. Ibis 125:524-544. https://doi.org/10.1111/j.1474-919X.1983.tb03146.x

Terborgh, J. 1990. Mixed flocks and polyspecific associations: costs and benefits of mixed groups to birds and monkeys. American Journal of Primatology 21:87-100. https://doi. org/10.1002/ajp.1350210203

White, G. C., and K. P. Burnham. 1999. Program MARK: survival estimation from populations of marked animals. Bird study 46:120-139. https://doi.org/10.1080/00063659909477239

Whittingham, M. J., and K. L. Evans. 2004. The effects of habitat structure on predation risk of birds in agricultural landscapes. Ibis 146:210-220. https://doi.org/10.1111/j.1474-919X.2004.00370.

$\mathrm{x}$

Willson, M. F., J. L. Morrison, K. E. Sieving, T. L. De Santo, L. Santisteban, and I. Díaz. 2001. Patterns of predation risk and survival of bird nests in a chilean agricultural landscape. Conservation Biology 15:447-456. https://doi.org/10.1046/ j.1523-1739.2001.015002447.x 